\title{
Archaeological Monitoring of a Parking Lot Construction Project in New Braunfels, Comal County, Texas
}

John W. Arnn III

Center for Archaeological Research

Follow this and additional works at: https://scholarworks.sfasu.edu/ita

Part of the American Material Culture Commons, Archaeological Anthropology Commons, Environmental Studies Commons, Other American Studies Commons, Other Arts and Humanities Commons, Other History of Art, Architecture, and Archaeology Commons, and the United States History Commons

Tell us how this article helped you.

This Article is brought to you for free and open access by the Center for Regional Heritage Research at SFA ScholarWorks. It has been accepted for inclusion in Index of Texas Archaeology: Open Access Gray Literature from the Lone Star State by an authorized editor of SFA ScholarWorks. For more information, please contact cdsscholarworks@sfasu.edu. 


\section{Archaeological Monitoring of a Parking Lot Construction Project in New Braunfels, Comal County, Texas}

\section{Creative Commons License}

\section{(c) (1) \&}

This work is licensed under a Creative Commons Attribution-NonCommercial 4.0 International License 


\title{
Archaeological Monitoring of a Parking Lot Construction Project in New Braunfels, Comal County, Texas
}

\author{
John W. Arnn, III \\ Robert J. Hard and C. Britt Bousman \\ Principal Investigators
}

Texas Antiquities Committee Permit No. 1729

${ }^{\circledR}$ copyright

Center for Archaeological Research

The University of Texas at San Antonio

Archaeological Survey Report, No. 255

1997 
The following information is provided in accordance with the General Rules of Practice and Procedure, Chapter 41.11 (Investigative Reports), Texas Antiquities Committee:

1. Type of investigation: Testing and monitoring

2. Project name: New Braunfels Parking Lot

3. County: Comal

4. Principal investigators: Robert J. Hard and C. Britt Bousman

5. Name and location of sponsoring agency: City of New Braunfels; 424 S. Castell; New Braunfels, Texas 78130

6. Texas Antiquities Committee Permit No.: 1729

7. Published by the Center for Archaeological Research, The University of Texas at San Antonio, 6900 N. Loop 1604 W., San Antonio, Texas 78249-0658, 1996.

A list of publications offered by the Center for Archaeological Research is available. Call (210) 458-4378; write to the Center for Archaeological Research, The University of Texas at San Antonio, 6900 N. Loop 1604 W., San Antonio, Texas 78249-0658; e-mail to car@lonestar.utsa.edu; or visit CAR's Web site at http://www.csbs.utsa.edu/research/car/index.htm. 


\section{Abstract}

In August 1996, the Center for Archaeological Research (CAR) of The University of Texas at San Antonio was contracted by the city of New Braunfels to conduct archaeological investigations prior to planned development of vacant city property. The plan called for the construction of a parking lot in close proximity to site $41 \mathrm{CM} 25$, an Archaic-period cemetery. The investigation was to determine whether the proposed construction would impact site $41 \mathrm{CM} 25$ or other prehistoric and/or historic features. CAR staff conducted a pedestrian survey of the project area, shovel tested in the footprint of the proposed parking lot, and monitored tree stump removals and subsurface grading necessary for the parking lot construction. In addition, two backhoe trenches were excavated and one geological profile was described.

The testing and monitoring uncovered various prehistoric and historic artifacts in good archaeological and geological contexts. Most of the artifacts were prehistoric and included chert flakes, cores, mussel shell, and fire-cracked rock. One diagnostic artifact-a Pedernales point-was uncovered, tentatively assigning the site to the Middle Archaic period. The results of the geological profile, in conjunction with background research, suggest that the project area is located on the edge of a distinctive geological zone in which the burial site of 41CM25 is located.

The testing and monitoring concluded that numerous buried cultural deposits are located in the project area and that the presence of buried cultural features is also highly probable. However, due to the relatively shallow depth required for the footings of the parking lot, these deposits and features will not be significantly impacted by the construction process. In addition, the close proximity of the project area to the existing site 41CM25, combined with the geological evidence, suggests that this area is one contiguous site. Therefore, we recommend that the boundaries of site $41 \mathrm{CM} 25$ be extended to include the project area and that any future development of 41CM25 and/or the project area be closely monitored and evaluated by archaeologists. 


\section{Contents}

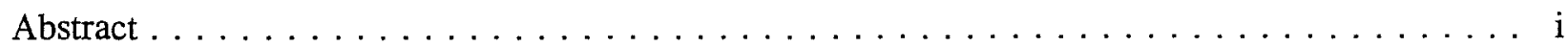

List of Figures $\ldots \ldots \ldots \ldots \ldots \ldots \ldots \ldots \ldots \ldots \ldots \ldots \ldots \ldots$ ii

List of Tables $\ldots \ldots \ldots \ldots \ldots \ldots \ldots \ldots \ldots \ldots \ldots \ldots \ldots \ldots$ iii

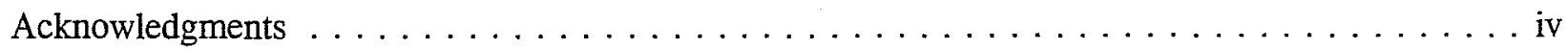

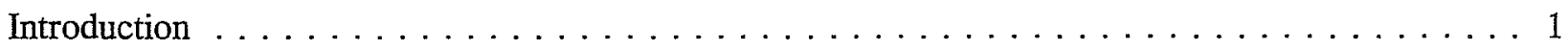

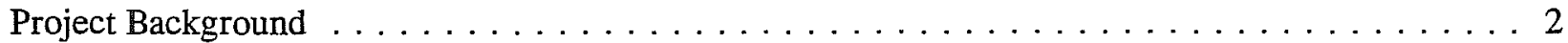

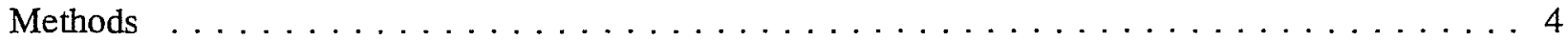

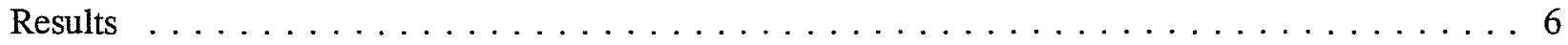

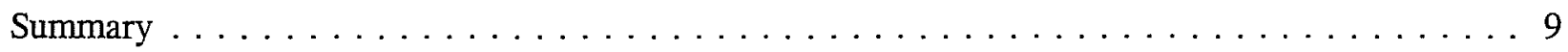

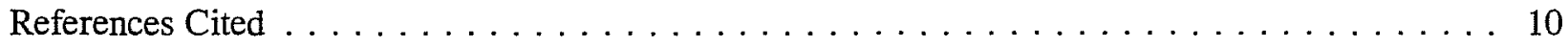




\section{Figures}

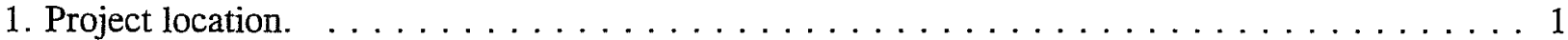

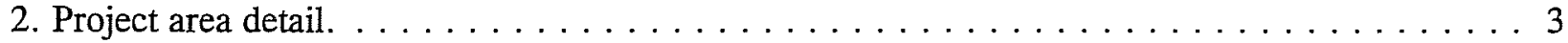

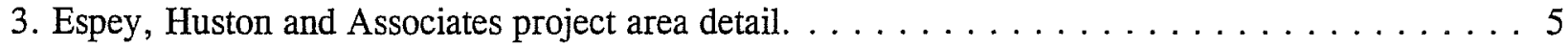

4. Prewitt and Associates project area detail (Bailey and Bousman 1989) . . . . . . . . . . . . 7

\section{Tables}

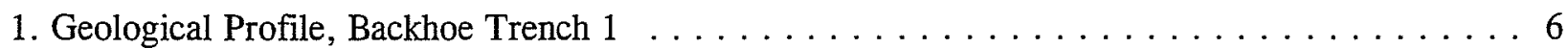

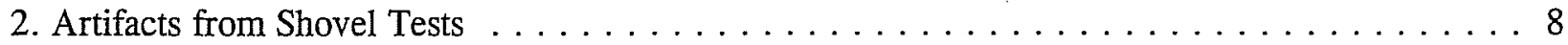




\section{Acknowledgments}

This project would not have been possible without the close communication and cooperation of Mr. Clarence Bolner, city engineer for New Braunfels. I would like to thank the principal investigators, Robert J. Hard and C. Britt Bousman, for their advice and support. Thanks are also in order to Jeff Durst for his assistance in several phases of this project and his recording of the geological profile, to Bruce Moses for his excellent drafting skills, and finally to Marcie Renner for her superb editorial talent and patience. 


\section{Introduction}

In August 1996, the Center for Archaeological Research (CAR) of The University of Texas at San Antonio was contracted by the city of New Braunfels to conduct archaeological investigations prior to the construction of a parking lot between the New Braunfels Presbyterian Church and the Girl Scout meeting house grounds.
The investigations were conducted to evaluate the potential impacts of construction on archaeological resources. After consultation with Mark Denton of the Texas Historical Commission, CAR conducted a pedestrian survey and one day of shovel testing, and excavated and documented two backhoe trenches in the footprint of the parking lot area. In addition, archaeologists monitored all excavations and grading associated with construction of the parking lot.

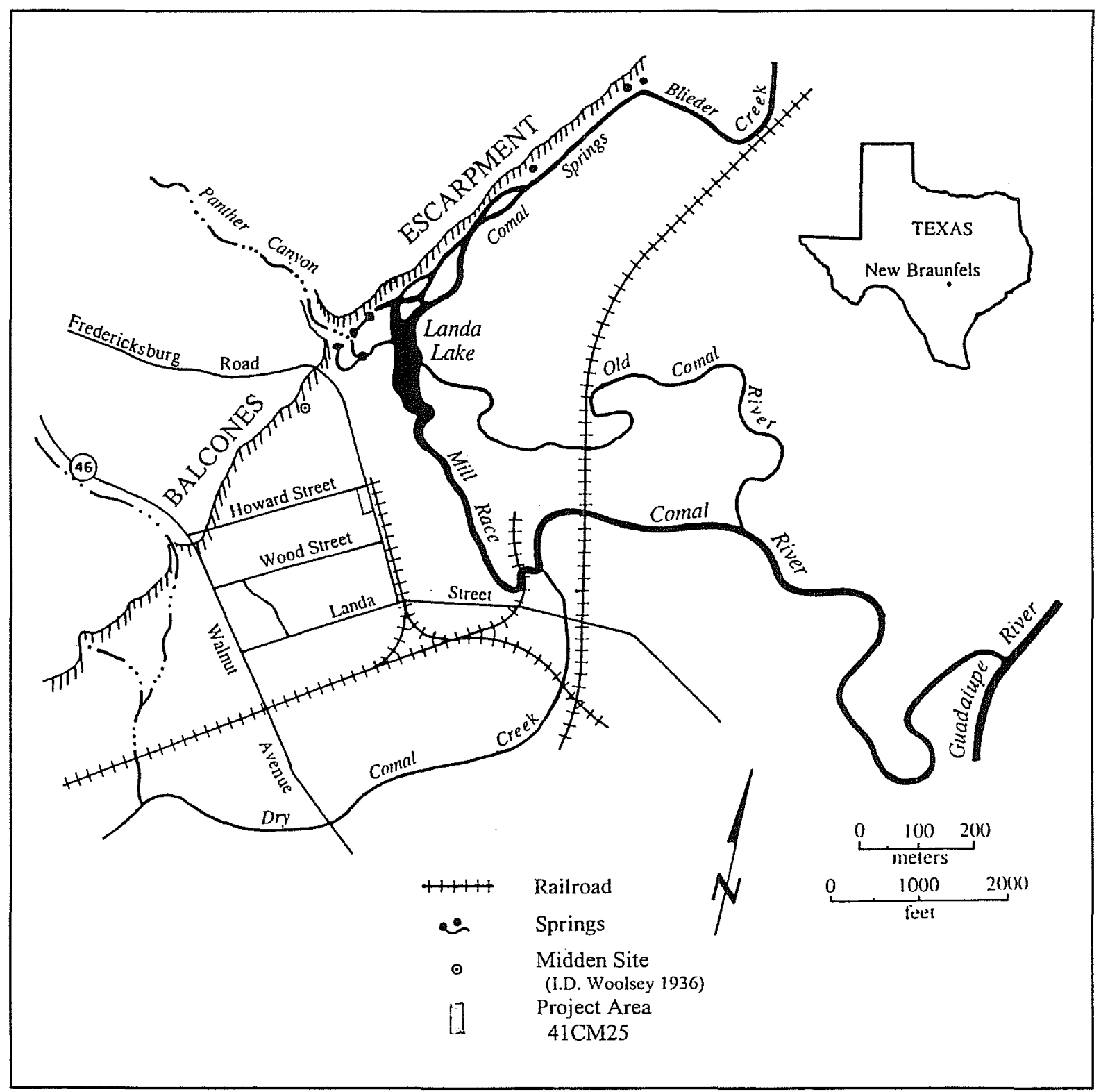

Figure 1. Project location. 


\section{Project Background}

The project area is located less than $500 \mathrm{~m}$ east of the Balcones Escarpment and less than $600 \mathrm{~m}$ south of Landa Lake (Figure 1). The lake was formed by the construction of a dam in 1847 , effectively pooling the flow of several large springs (Haas 1968). To the northeast the site is bounded by Fredericksburg Road, on the northwest side by Howard Street, on the southeast side by residences, and on the southwest side by the New Braunfels Presbyterian Church (Figure 2).

Five sites have been documented within $400 \mathrm{~m}$ of the project area. This area was defined as part of a much larger site, 41CM25, in 1989 by Espey, Huston, and Associates (EHA) (Bailey and Bousman 1989; Denton 1986, 1987; Smith 1985). At least one reason for this plethora of sites is the above-mentioned springs. The springs result from ground water flowing through the Lower Cretaceous limestones of the Edwards Plateau and percolating up through fissures in the Balcones fault zone (Brune 1981:129). The Balcones Escarpment also marks the convergence of many plant and animal species as it makes the transition from the Edwards Plateau to the Blackland Prairie (Diamond et al. 1987). Early chroniclers noted a wide variety of plant species including palmetto, oak, mesquite, cypress, red cedar, and elm (Roemer 1935). This biodiversity is consistent with later reports (Brune 1981; Haas 1968), including Bailey's description of the vegetation as a combination of southern Blackland Prairie and Mesquite-Chaparral Savanna (Bailey 1986:4).

The biodiversity, combined with abundant and predictable water, created a tremendous resource base for both prehistoric and historic peoples. Early historic accounts remark on the numbers of native peoples and the suitability of the area for colonization (Brune 1981; Roemer 1935). The archaeological record further strengthens these accounts and has been well documented at other spring-related sites along the Balcones Escarpment (Riklis et al. 1991; Shiner 1983; Takac et al. 1992).
In July 1929, the New Braunfels Herald reported that several burials were found at a depth of 76 $\mathrm{cm}$ in sandy, calcium carbonate-rich sediments (Bailey and Bousman 1989). Albert Nowotny, an amateur archaeologist, is generally credited with bringing the existence of buried prehistoric remains to the attention of the public by displaying them in the window of his museum, The House That Jack Built (Bailey and Bousman 1989).

Excavations conducted by The University of Texas in 1936 and headed by J. E. Pearce, A. T. Jackson, and A.M. Woolsey revealed 19 prehistoric burials adjacent to the project area (Figure 2) (Woolsey et al. 1936). Unfortunately, virtually all the burials had been disturbed, and the excavation of an area approximately $41 \mathrm{~m}$ $(135 \mathrm{ft})$ long, $9 \mathrm{~m}$ (30 ft) wide, and $1.4 \mathrm{~m}(4.5 \mathrm{ft})$ deep revealed that the area was honeycombed with looters' pits (Woolsey 1936:64). The University of Texas team estimated, based on conversations with the locals, that roughly 75 burials had been removed by amateurs, road and sewer crews, and university excavators (Woolsey 1936:64). There was no specific orientation to the burials, which were all flexed and averaged 54.8 inches $(138.5 \mathrm{~cm})$ in depth. Grave goods were found with only six of the burials, but it is highly probable that most of the goods had been looted before archaeologists arrived. Local collectors Ed Smith and Ad Forke reported finding a boatstone above the mandible of one burial and a conch shell gorget on the chest of another (Woolsey 1936).

In papers not included with the original report, numerous artifacts are described. These objects were apparently found in the vicinity of the burials and reported later to The University of Texas (Woolsey 1936). At least one of these collections came from an area $402 \mathrm{~m}$ (.25 mile) northwest of the burial site (Figure 1) and was referred to only as the "midden" (Woolsey 1936:71). The miscellaneous collections include several knives, scrapers, a mano, at least one skull which was donated to the university, and several projectile points (Woolsey et al. 1936). 


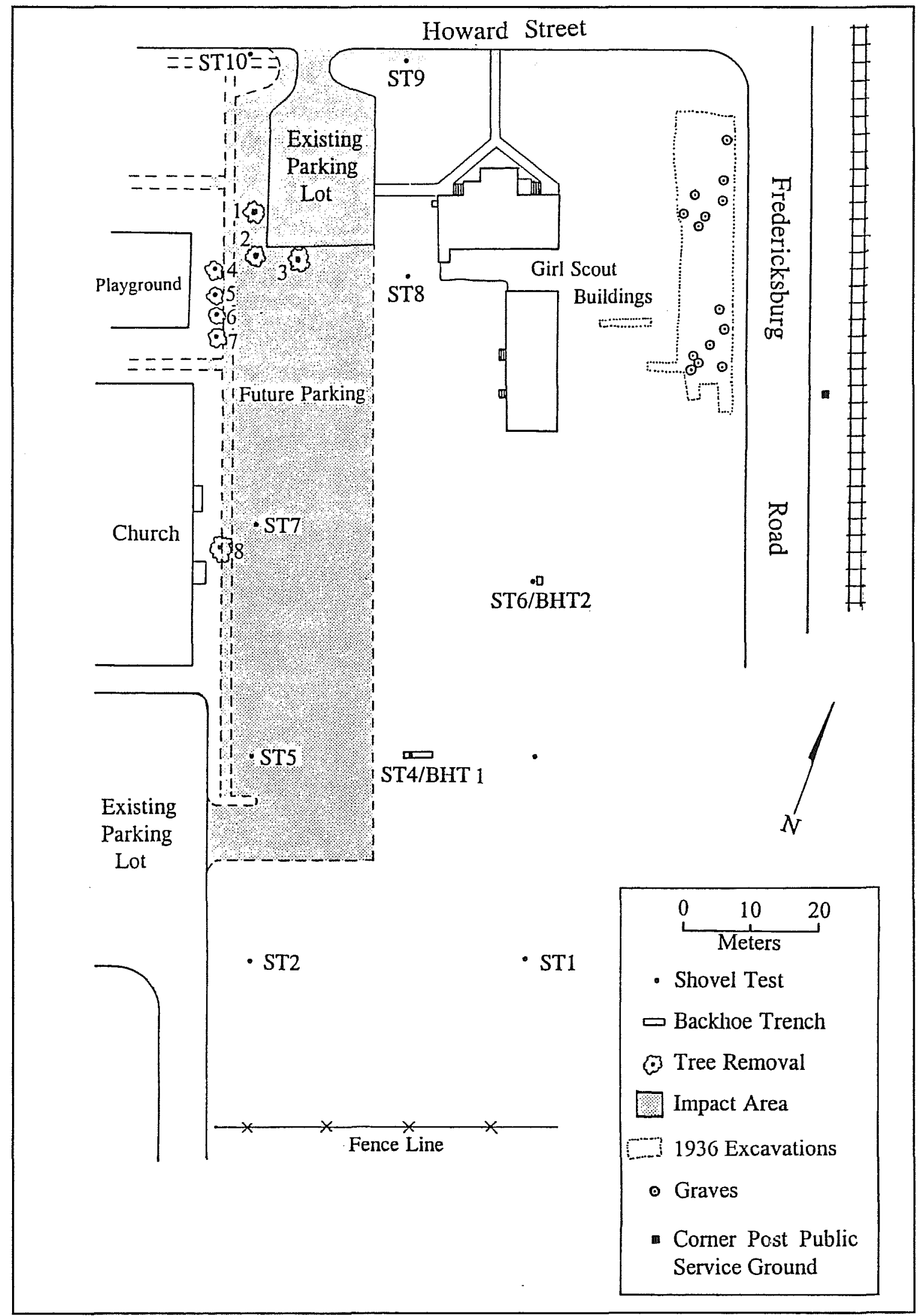

Figure 2. Project area detail. 
Bailey and Bousman (1989) report that projectile points found near the burials include Marshall, Bulverde, Williams/Castroville, and Perdiz (Bailey and Bousman 1989:12). In addition, Bailey and Bousman (1989:12) suggest an age range for site 41CM25 from the Middle Archaic period to the Austin phase of the Neoarchaic period based on the projectile points, flexed position of the burials, and grave goods. In January 1986, Mark Denton of the Texas Historical Commission recorded a small Late Prehistoric site roughly $250 \mathrm{~m}$ northeast of the project area. The site contained small hearths, chert flakes, bone, and ceramic sherds (Denton 1986).

In the fall of 1992, EHA monitored the installation of five utility poles within and immediately north of the project area (Figure 3). EHA described geologic profiles of the holes dug for the installation of the poles, and excavated a 1-x-1-m unit in site 41CM205 (Figure 3). They noted that below the historic plow zone, soil deposits were relatively undisturbed, which is consistent with local accounts of land usage (Bailey and Bousman 1989; EHA 1992). Hole 1 produced no cultural material and Hole 2 produced only a few flakes (EHA 1992:28). However, the 1-x-1-m excavation unit, which corresponded to the location of Hole 3 , produced over 2,400 lithic artifacts. These artifacts included diagnostic projectile points reflecting a temporal assignment from the Paleoindian to the Middle Archaic periods (EHA 1992:30). Hole 4 produced only burned rock, but Hole 5, though extensively disturbed, showed a dense concentration of burned rock between 20 and $60 \mathrm{~cm}$ as well as flakes and chert cobbles (EHA 1992:29).

The historic record in New Braunfels is relatively old for the state of Texas. As early as 1844 the German Emigration Company was sending colonists to Texas, which led to the establishment of New Braunfels in 1845 (Haas 1968). In 1846 George Klaffenbach acquired block No. 158 which consisted of 50 acres stretching from the Balcones Escarpment to present day Landa Street, bounded on the east by Fredericksburg Road and on the west by Parkview Boulevard (Figure 3)
(Bailey and Bousman 1989:9). This 50-acre block was eventually sold off in portions; however, the Klaffenbach homestead still exists and has been designated site 41CM184. According to local informants, land use of the project area was consistently agricultural until about 1939 (Bailey and Bousman 1989:9). Sometime after 1939 the Girl Scout meeting house-which lies between the parking lot and the 1936 excavations (Figure 2)was built. Construction of the New Braunfels Presbyterian Church began in 1967(Bailey and Bousman 1989:9).

\section{Methods}

Fieldwork began on August 14, 1996, with a pedestrian survey of the project area. The pedestrian survey was conducted by two CAR staff members. The ground cover-primarily grasses-was light to moderate.

Initial conversations with the city engineer, Clarence Bolner, indicated that the proposed construction required grading the existing surface with a maintainer, in some areas, as much as 58 $\mathrm{cm}$ below the existing surface. As was noted above, according to Woolsey's notes the average depth of burials was 54.8 inches $(138.5 \mathrm{~cm})$. However, at least two of the burials were as shallow as 38 and 39 inches $(96-100 \mathrm{~cm})$ (Woolsey 1936:41, 51). This information, combined with the close proximity-in some cases less than $50 \mathrm{~m}$ (Figure 2)-to the previous burial excavations, persuaded Mr. Bolner to increase the amount of fill, raising the existing surface considerably. So much so, in fact, that less than $10 \mathrm{~cm}$ of the existing surface required grading and monitoring, and this was confined to a relatively small area of less than $60 \mathrm{~m}^{2}$.

Ten shovel tests (STs) were excavated by two CAR personnel within the footprint of the proposed parking lot (Figure 2). The shovel tests were excavated in $10-\mathrm{cm}$ levels to a depth of 50 $\mathrm{cm}$ and soil from each level was screened through $1 / 4$-inch wire mesh to facilitate the recovery of cultural material. 
This page has been

redacted because it

contains restricted

information. 
wall of the trench was described (Table 1), and soil samples were collected from the each stratigraphic level. BHT 2, in association with ST 6 , was two meters long and excavated to a depth of $120 \mathrm{~cm}$.

Eight tree stumps were removed from the northwest edge of the survey area using a backhoe. Monitoring was conducted during the removal of the tree stumps and artifacts were collected.

All projectile points were compared to typological definitions and temporal assignments in Turner and Hester (1993). Nondiagnostic artifacts were classified as flakes, shatter, core, uniface, biface, heat-damaged chert, fire-cracked rock, and mussel shell (Whitaker 1994). Historic artifacts consisted primarily of assorted construction debris in the form of broken fragments of clear glass, brick, and metal. The Historic artifacts were associated with the construction of the Presbyterian church.

\section{Results}

\section{Geology}

A single profile was described in BHT 1. The profile indicates that a soil developed on finegrained sediments which lie upon a level of caliche underlain by yet another level of caliche
(Table 1). This profile does not resemble any of those described by Bailey and Bousman (1989:16-19). However, the profile described in Table 1 is consistent with the profile description of Hole 1 in the EHA report. "The soil, to a depth of approximately $3 \mathrm{~m}$, was a very pale brown coarse sand . . Below $3 \mathrm{~m}$, the soil changed to a light yellowish brown sand.. . This soil continued to a depth of about $8 \mathrm{~m}$, where limestone bedrock was encountered" (EHA 1992:28). This is markedly different from Holes 2 and 3 , which note dense river gravels at a depth of approximately eight meters, suggesting the presence of a buried stream bed (EHA 1992:28-29).

Zone 3 in Table 1 is consistent with a New Braunfels Herald report of 26 July 1929. The newspaper reported that burials were found at a depth of $76 \mathrm{~cm}$ in sandy, calcium carbonate-rich sediments. Level 3 in Table 1 lies between 59 and $82 \mathrm{~cm}$ and is composed of loose, friable, sandy caliche with numerous $\mathrm{CaCO}_{3}$ inclusions. This suggests that the geomorphology of the 1929 burial excavations, our Backhoe Trench 1, and EHA's Hole 1 is similar.

Furthermore, the soils described in the New Braunfels Herald, Hole 1, and Table 1 appear to be an isolated phenomenon. The location of the Bailey and Bousman profiles (Figure 4), effectively bounds the southwest and southeast

Table 1. Geological Profile, Backhoe Trench 1
Zone Depth (cm)
Description
1 0-13 Dark brown (10YR4/1) clay loam, fine subangular blockystructure, common snail shell fragments, gradual smooth lower boundary, A Horizon.
2 13-59 Dark grayish brown (10YR5/3) clay loam, fine subangular blocky structure, commo snail shell fragments and whole shells, $\mathrm{CaCO}_{3}$, abrupt to clear wavy boundary, $\mathrm{AB}$ Horizon.
3 59-82 Pinkish white (5YR8/2) sandy caliche, loose friable, weak blocky structure, $\mathrm{CaCO}_{3}$ inclusions, abrupt to clear smooth boundary.
4 82-123 Pink (7.5YR8/4) sandy caliche, loose friable, weak blocky structure, $\mathrm{CaCO}_{3}$ inclusions, lower boundary not observable. 


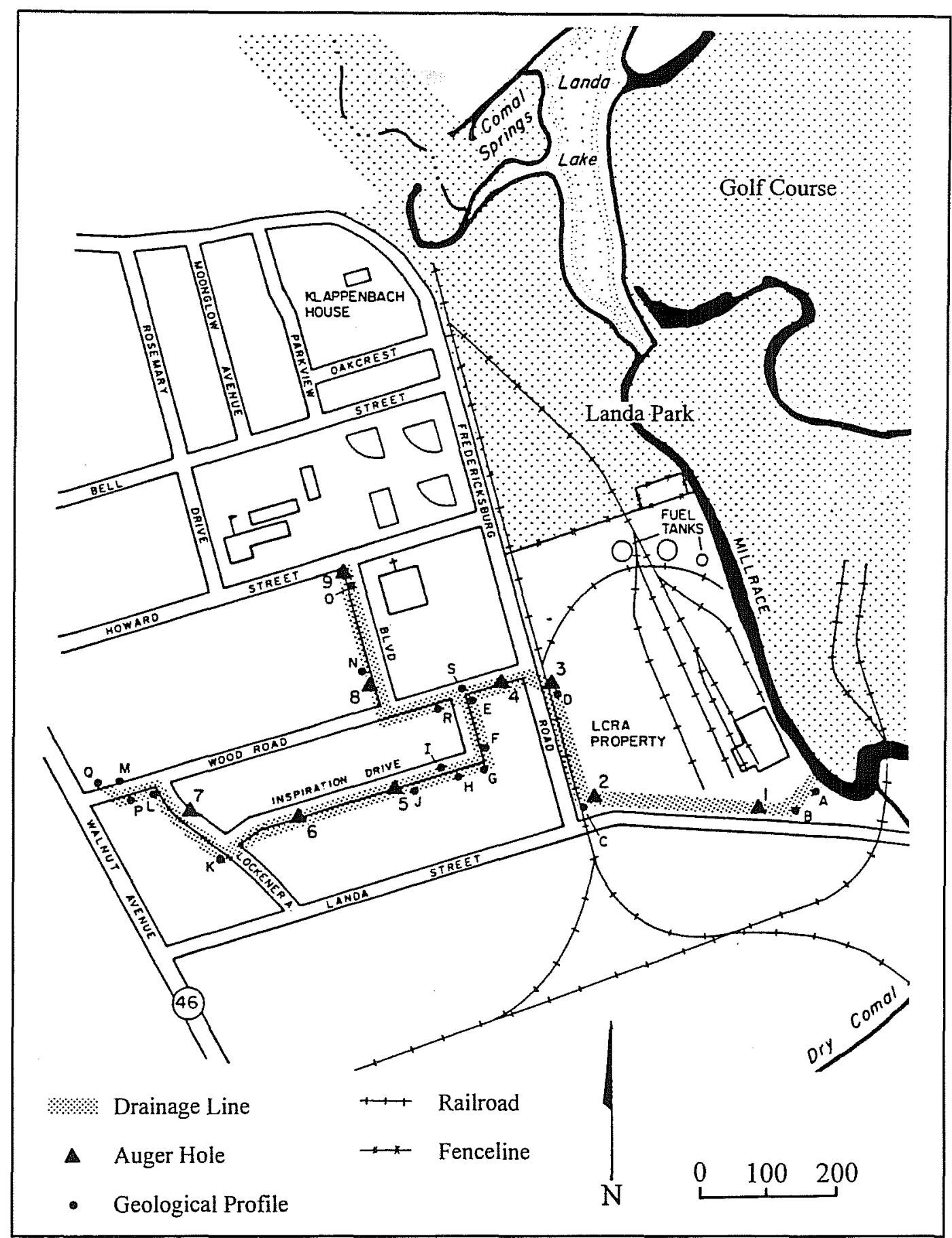

Figure 4. Prewitt and Associates project area detail (Bailey and Bousman 1989).

edges of the project area and delineates an area of markedly different subsurface geomorphology. EHA work, with respect to Holes 2-5, effectively bounds the northern edge of the project area and confirms the earlier work of Bailey and Bousman which suggested the presence of a subsurface stream bed. In addition, Woolsey noted that the burial excavations of 1936 were located "on a little knoll" which corresponds to the slight rise which now marks the location of the project area (Woolsey 1936:1).

The above information indicates the burials were originally placed in a specific area which can be 
recognized as a slight rise or knoll on the surface The area may also be recognized below the surface by its site-specific geomorphological characteristics (Table 1). The subsurface geomorphology is characteristic of levee deposits associated with an old streambed, which was identified by Bailey and Bousman (1989) and EHA (1992).

While the significance of the subsurface geomorphology may or may not have been important to prehistoric peoples, its significance should not be lost on contemporary as well as future investigators. The fact remains that the subsurface deposits appear to be an isolated feature and as such may be indicative of previous cultural activity and its associated artifacts.

\section{Pedestrian Survey}

A pedestrian survey of the project area revealed a light scatter of chert, mussel shell, and firecracked rock on the surface, suggesting a multiuse habitation site. No diagnostic artifacts were found and no artifacts were collected. Future investigators should also note that the project area is used by the Girl Scouts for campfire functions and related activities. Thus the surface of the project area has several modern hearth features and at least one modern tepee ring.

\section{Shovel Testing}

Of the 10 shovel tests excavated, all but STs 9 and 10 contained cultural material. While cultural material was encountered from $0-50 \mathrm{~cm}$ below the surface, the highest concentrations occurred between 20 and $40 \mathrm{~cm}$ below ground surface. The vast majority of cultural materials found were chert flakes (Table 2). However, two cores were also found, one in ST 4 between 40 and $50 \mathrm{~cm}$ and one in ST 8 between 30 and $40 \mathrm{~cm}$. A Pedernales projectile point, found in ST 4 at a depth of 20-30 cm, indicates a tentative temporal assignment to the Middle Archaic period (Turner and Hester 1993). In addition, there was a relatively high frequency of fire-cracked rock (FCR) 14 total, second only to chert flakes in numbers (Table 2). The relative abundance of FCR may indicate a habitation or food preparation

Table 2. Artifacts from Shovel Tests

\begin{tabular}{|c|c|c|c|c|c|c|c|c|c|c|}
\hline Depth $(\mathrm{cm})$ & ST 1 & ST 2 & ST 3 & ST 4 & ST 5 & ST 6 & ST 7 & ST 8 & ST 9 & ST 10 \\
\hline $0-10$ & & & 3 flks & & & $1 \mathrm{flk}$ & 4 flks & 1 glass & & \\
\hline \multirow{2}{*}{$10-20$} & $1 \mathrm{flk}$ & & & 3 flks & & 2 flks & 4 flks & & & \\
\hline & & & & 2 FCR & & & $1 \mathrm{FCR}$ & & & \\
\hline \multirow{3}{*}{$20-30$} & 2 flks & $1 \mathrm{flk}$ & & $8 \mathrm{flks}$ & $1 \mathrm{flk}$ & 5 flks & 3 flks & 3 flks & & \\
\hline & 5 FCR & & & 1 mussel sh. & & 1 nail & & & & \\
\hline & & & & 1proj.pt. & & & & & & \\
\hline \multirow{3}{*}{$30-40$} & 2 flks & $1 \mathrm{flk}$ & & $9 \mathrm{flks}$ & $1 \mathrm{flk}$ & & & 2 flks & & \\
\hline & & & & $1 \mathrm{FCR}$ & 1 mussel sh. & & & $1 \mathrm{FCR}$ & & \\
\hline & & & & & & & & 1 core & & \\
\hline \multirow{2}{*}{$40-50$} & & & & $1 \mathrm{flk}$ & & 2 flks & & & & \\
\hline & & & & 1 core & & $1 \mathrm{FCR}$ & & & & \\
\hline
\end{tabular}


site. The two shovel tests which produced no cultural material were located in disturbed fill adjacent to Howard Street.

\section{Monitoring}

BHT 1 was located adjacent to ST 4 due to the high artifact frequency in 4 . However, monitoring uncovered only 15 flakes, 5 fire-cracked rocks, and 2 pieces of heat-damaged chert from $0-50 \mathrm{~cm}$ and only 7 flakes and 1 fire-cracked rock from $50-125 \mathrm{~cm}$. The combined totals of artifacts from both levels of BHT 1 , representing roughly $5 \mathrm{~m}^{3}$, was 30 , compared to 27 artifacts out of ST 4 , representing less than $0.125 \mathrm{~m}^{3}$. BHT 2 contained no artifacts.

With the exception of number 1 , all tree stump removals contained cultural material. Stump removal 4 contained a projectile point between 20 and $50 \mathrm{~cm}$ below the surface. However the point was so badly damaged, lacking either stems and/or shoulders, that it was impossible to type with any degree of accuracy. Stump removal 8 contained a non-diagnostic biface fragment. Stump removals $2-8$ contained chert flakes also at depths of 20-50 cm below the surface.

The grading operation produced only six flakes and one slightly worked uniface. As mentioned above, however, the actual cut was less than $10 \mathrm{~cm}$ deep out of a total surface area of $60 \mathrm{~m}^{2}$.

\section{Summary}

Testing and monitoring of the project area determined the presence of buried cultural deposits in good archaeological and geological contexts. These deposits, based on the temporal assignment of the Pedernales projectile point, probably date from the Middle Archaic period, which is contemporaneous with the burial site 41CM25. The geological profile described above, combined with those of Bailey and Bousman (1989), the July 26, 1929, New Braunfels Herald report, and the EHA report (1992) also suggests a close subsurface relationship between site $41 \mathrm{CM} 25$ and the project area. Finally, even today there is a definitive rise or hummock in the same location as the "knoll" described by Woolsey in 1936 (Woolsey 1936:1). In addition, the artifacts associated with Hole 5 in the EHA report correspond well with Woolsey's location for the midden (Woolsey 1936:71). Due to the extremely dense distribution of cultural deposits both in and adjacent to the project area we recommend that any future development of the project area and/or site $41 \mathrm{CM} 25$ be closely monitored by archaeologists. Furthermore, we strongly recommend that the boundaries of site $41 \mathrm{CM} 25$ be extended to include the project area. 


\section{References Cited}

Bailey, G.

1986 Archaeological Investigations In Landa Park, City of New Braunfels, Comal County, Texas. Letter Report No. 330. Prewitt and Associates, Austin.

Bailey, G. L., and C. B. Bousman

1989 Subsurface Archaeological Survey and Monitoring of the Landa Street/ Fredericksburg Road Drainage Improvement Project, Comal County, Texas. Technical Reports No. 6. Prewitt and Associates, Austin.

Brune, G.

1981 Springs of Texas. Vol. 1. Branch-Smith, Fort Worth.

Denton, $\mathrm{M}$.

1986 Field notes, 41CM76. On file, Texas Historic Commission, Austin.

1987 Field notes, 41CM75. On file, Texas Historic Commission, Austin.

Diamond, D. D., D. H. Riskind, and S. L. Orzell

1987 A Framework for Plant Community Classification and Conservation in Texas. The Texas Journal of Science 39:3:203-221.

Espey, Huston and Associates (EHA)

1992 Archaeological Monitoring and Testing of the Landa Park to Krueger Canyon Road Transmission Line Rebuild Project Comal County, Texas. Espey, Huston and Associates, Austin.

Haas, $\mathrm{O}$.

1968 The History of New Braunfels and Comal County, 1844-1946. Steck, Austin.

New Braunfels Herald

1929 Men Dig Up Eight Skeletons While Excavating Ditches. 26 July:1

Ricklis, R. A., M. D. Blum, and M. B. Collins

1991 Archeological Testing at the Vera Daniel Site (41TV1364), Zilker Park, Austin, Texas. Studies in Archeology 12. Texas Archeological Research Laboratory, The University of Texas at Austin.

Roemer, F.

1935 Roemer's Texas. Texian, San Antonio

Smith, H.

1985 An Assessment of Archaeological Resources in Landa and Cypress Bend Recreation Areas, New Braunfels, Texas. Manuscript on file. Texas Historical Commission, Austin

Shiner, J. L.

1983 Large Springs and Early American Indians. Plains Anthropologist 28:1-7. 
Takac, P. R., P. Goldberg, and S. Valastro

1992 Archeological and Geomorphological Testing Along the Proposed South Austin Outfall Relief Main, Phase II Tunnel Alignment: The Vara Daniel Site (41TV1364), Zilker Park, Austin Texas. Technical Series 28. Texas Archaeological Research Laboratory, The University of Texas at Austin.

Turner, E. S., and T. R. Hester

1993 A Field Guide to Stone Artifacts of Texas Indians. Second Edition. Gulf, Houston.

Whitaker, J. C.

1994 Flintknapping, Making and Understanding Stone Tools. University of Texas Press, Austin.

Woolsey, A. M., J. E. Pearce, and A. T. Jackson

1936 Notes on Field Work, H. C. Locke Farm, 1 Mile West of New Braunfels, Comal County, Texas. On file, Texas Archaeological Research Laboratory, The University of Texas at Austin. 
